\title{
Research on the Ability and Quality of College English Teachers Against the Backdrop of Educational Globalization
}

\author{
Sun Huayan \\ Humanities and International Education College \\ Xi'an Peihua University \\ Xi'an, China \\ 315112580@qq.com
}

\begin{abstract}
This paper mainly analyzes the development of the global education and the new requirements to the teachers, especially the English teachers. It aims to identify the ability and quality that the college English teachers should possess against the backdrop of educational globalization. As the international communication is becoming more and more frequent, it is of vital importance to education. Educational globalization helps different countries to know each other well. Education is also keeping pace with the times. Global education pays more attention to the students' social competence and the various qualities. According to the comparison with previous education, new requirements are put forward for English teachers in this paper. Meanwhile this paper analyzes the use of the foreign language and conducts a deep research on the meaning and the role of English. So it is concluded that against the new backdrop of education, the college English teachers should open their view in an international way and deliver advanced ideas to students.
\end{abstract} Quality

Keywords-Educational globalization; Teaching ability;

\section{INTRODUCTION}

With the development of globalization, the connection of the world is becoming more and more close, which promotes the political, economic, scientific and technological culture interflow among the world, which also accelerates the improvements of the education. With the development of the globalization, the higher education faces many new chances and great challenges. The era endows new requirements to the college English teachers. So this paper mainly analyzes the quality and ability that the college English teachers should obtain under the background of educational globalization.

\section{THE DEFINITION OF EDUCATIONAL GLOBALIZATION}

The economic globalization and the liberalization of international trade certainly promote the educational globalization. The global resources allocate among the countries and the educational communication and cooperation becomes more and more frequently. The world education influences, competes, mixes each other. The world enters China and China goes into the world. Educational globalization is the new educational dream and the teaching practice that carried out in the whole world.
In academia, there are many definitions for educational globalization. It's believed that educational globalization embodies on the modernization, integration and internationalization of the education. The features of the educational globalization are blurry, multiple and complicated. So the general definition is that educational globalization is the outcome of the development of the society. It breaks the cultural, social, special and institutional barriers of the different cultural system in different world. It also realizes the objective to share the information and resources and promotes the communication among different districts. It helps to achieve the unification of the educational aims. Meanwhile, educational globalization is a process of modernization, which includes multi-layered and multistage historical and cultural contents.

With the direction of the educational globalization, each country tries their best to develop the excellent domestic and overseas educational field. They allocate the educational resources and grasp the chances of international education. The ultima purpose of the educational globalization is to cultivate the talents with international consciousness, communicational ability and the international competence. These talents base on their own country, set their sight on the world and has the ability to compete in the world. This is the trend of educational globalization. And the English teaching in the college must face the challenge.

\section{THE NEW REQUIREMENTS FOR COLLEGE ENGLISH UNDER THE GLOBALIZATION}

Under the background of globalization, the new requirements for the talented persons are like this: the open global outlook, effective communication ability, intercultural communication and collaboration, the ability to solve the complicated problems, the ability to face new challenges and the potential to be the leading talented person both in China and the whole world, [6] the ability to think independently and innovation, the ability to study, live and work under the English environment. So English teaching has the essential role in cultivating the international talented persons.

To improve the ability to cope with the trend of globalization, our educational system can strengthen the reformation according to the advanced foreign educational and 
management system. Meanwhile, we should create a better environment for study associated to the current situation. The college should pay more attention to the training of the talents and apply the advanced educational and scientific technology to improve the evaluation system. We should amend some subjects according to the real teaching process. We should try some new teaching modes by different materials to stimulate the teaching interests.

To adapt to the educational globalization, English teaching plays a more and more important role. We should use the college English teaching to improve the students' language ability. Train the students to have the international view. According to the learning of English literature, the students can know the culture of western country. And they have the ability and the passion to know the western. So the main task of the English teaching is to develop the students' communication and understanding of the western country.

\section{RESEARCH ON THE QUALITY AND ABILITY OF COLLEGE ENGLISH TEACHERS}

The Global English (Global Culture Studies) major focuses on practical and theoretical issues encountered in cross-cultural interactions all over the world, and it studies the traditional cultural products (literature, film, visual arts, music, social media, new technologies, etc.) and more extensive political and social background (colonialism, modernization, capitalism, etc.). [3]The English (Global Culture Studies) major takes literature as the most important part to teach the students the critical thinking methods, the cultural analysis, the ability and skills of English communication, which provides the preparation for the career of their education, creative industries, NGOs and international business and law.

The professionalization of the teachers mainly emphasizes the group and external improvements. While the professional development of teachers is the process of the individual and internal professional improvement, which is the continuous updating and evolution of teachers' internal professional structure.

Nowadays the teachers must possess a comprehensive cultural quality, a solid professional quality, and a dedication to professionalism. They must have the ability to innovate the teaching methods, the ability to carry out the teaching research, the ability to develop social interaction, the ability to manage the information and predict the education future. These are all the requirements for the professional development of teachers.

According to the teachers' professional structure, the teachers' professional development has different aspects such as concept, knowledge, ability, professional attitude motivation, and self-professional development awareness. The Holmes Group's report named "Teachers' Future" suggests that the professional education of teachers should at least include the following aspects: regarding the teaching and school education as a complete subject; the knowledge of subject education, that is the ability to translate "personal knowledge" into "interpersonal knowledge"; the basic knowledge and technology needed in the class teaching; the unique qualities, values and ethical responsibility of the teaching profession and the guidance of teaching practice. The development from a new teacher to the mature one reflects their professional growth. From the stage of "standing on the platform" to "standing the platform firmly" to "standing the platform excellently", it shows the agreement to the career, the level of the development of psychological quality and the improvement of the career. The college English teachers must have steady professional, comprehensive human and professional moral qualities; they must have high teaching professional and innovative ability.

\section{A. The Humanity and Moral Quality}

With the influence of educational globalization, the foreign exchanges are becoming more and more frequent. As an excellent English teacher, we should remember our own work and professional ethics. We should base ourselves on the national education and actively guide the students. The college English integrates the cultural broadcast and creativity. As the cultural leader, interpreter and guardian, the English teachers should not only focus on the knowledge teaching, but also the guidance of cultural literacy to enlighten the students' intelligence and enhance their personality. Humanities quality not only includes humanistic knowledge, but also understand humanistic thinking and master the relative teaching methods. The teachers must devote themselves to the real teaching practice, connect the theories with the reality and infiltrate humanistic elements into each teaching periods. Then the teachers can enhance their teaching ability. So the college English teachers take an important role on importing the western culture and spreading the Chinese culture to the whole world.

With the background of the international education, the prerequisite for the training of the college English teachers is the cultivation of moral quality. The teachers should be the models for the students, whose actions and words have great influence for the students. Therefore, college English teachers must pay attention to their modularity and exemplary. Only by improving the English teachers' moral qualities, it can help to develop the teachers' cohesion and get progress of their career. The teachers' internal love of the education is the sole factor to keep the enthusiasm and vitality of their work, which helps to continuously improve the teaching abilities. The love and respect of the students, the concern about the students' situation of the study and life push the teaching work to go smoothly. And the teachers should treat each student equally to cultivate the students' confidence and stimulate their learning capacity. Only by loving the education cause from the heart can we always maintain the, and we can continuously improve the ability to teach and educate people; Only by loving students, respecting students, caring about students' learning and living conditions, treating each student equally can promote the smooth development of teaching work. The basic factor for educational globalization is the love of our country. So the English teachers should have strong patriotism. So in the future, the students will remember their love under the globalization. 


\section{B. The Professional Ability}

The college English teachers should not only master the theoretical knowledge of pronunciation, vocabulary, grammar, pragmatics, discourse, etc.; but also have excellent language application skills such as listening, speaking, reading, writing and translating. They should know the history, culture and customs of the Western countries. They should have the ability of cross-cultural communication skills and get familiar with the real situation of the relative field. The level and capacity of the college English teachers will directly affect the quality of teaching and the delivery of talents to the society.

An excellent English teacher is not only good at his own professional skills in listening, speaking, reading, writing, and translating, but to know the skills on how to teach the students well. With the direction of globalization, the teachers should make every effort to improve the teaching skills, which can determine the results of the class teaching. The teaching skills is not only related to the language ability, but closely connected with the psychology, pedagogy and professional knowledge. In a word, it is the epitome of the basic quality of teachers. So as the college English teachers, they should consciously improve their teaching ability which includes listening, speaking, reading and writing. Meanwhile they should develop some relative abilities such as language expression and application skills. The cognition, emotion, innovation and evaluation should also be applied in the teaching process.

\section{The Ability of Innovation}

"Individualized" teaching methods through "Knowledge without borders" is a major feature of education globalization.[5]Under this background, the college English teachers must be the first one to be energetic and then integrate the international education theory. The teachers should develop the students' intellectuality, individuality and the creative thinking. The purpose of international education is to help the students build their ability to adapt to the requirements of the international society. The college English teachers should provide the students an international and exoteric teaching environment where the students can be relaxed to learn the knowledge.

Teachers with strong creative ability will have a strong concept of teaching quality. A complete, effective and sustainable English teaching system can guarantee the quality of teaching and promote the internationalization of the teaching experience. Therefore, the English teachers should constantly update their educational concepts, adopt international teaching methods, innovation and practical abilities in education and teaching, and take up the responsibility of cultivating the students to be the international talents. The college English teachers should learn from the advanced foreign universities and get the curriculum design, furthermore they can work out the research courses that can catch up with the international certification and reach the results of the international teaching. During this system, the students can be immersed in different cultural background and then get the ability to innovate according to what they learned. Step by step, they can have the talent to meet the requirements of the international market.
In addition, innovative English teachers in the universities should not only know how to teach English knowledge, but also cultivate the students' self-inquiry learning, especially the international independent learning methods. Innovative English teachers should adopt the optimized teaching methods, and continue to inspire students' innovative learning ability according to their learning characteristics. The teachers should place emphasis on the cultivation of students' critical thinking ability, and encourage the students to think and to challenge the authority. Thus the teachers should encourage the development of the students' personality and use different teaching methods to teach different majors and different classes in the real situation.

\section{The Ability of Educational Technology}

The development of the educational technology runs rapidly. But technology is unlikely to replace teachers. So "What role will the teachers play in the future?" Technology will play a key role for this aspect. Educational technology not only brings the great changes in the form of education and learning, but gives deep influence on the ideas, concepts, models, contents and methods of education. The educational informatization requires the teachers to update from ideological concepts to practical methods. Only by mastering the modern educational and informational technology means, the teachers can satisfy the requirements of the educational informatization, improve the quality and efficiency of education and teaching and then get the developments of the profession. Educational technology has become the necessary skills and basic qualities of teachers as the foreign languages and computers. How to develop the teachers' networked teaching design, communicate with the students on line, evaluate the ability of learning, construct the ability of teachers' educational technology are the major concern. Educational informationization has laid a technical foundation and guarantee for the implementation of educational globalization.

Teachers should actively learn modern educational technology and learn online teaching. We are now realizing the fact that education is without borders, we can fully learn all kinds of excellent resources at home and abroad. As an English teacher, we should also incorporate international ideas and use advanced technology to urge students to learn English culture and corresponding international knowledge.

\section{SUMMARY}

To sum up, from the perspective of educational globalization, many western educational organizations and institutions have emerged in the process of education development in China. The combination of western education and eastern education has produced many new educational ideas and inspire the development of Chinese culture. It has a certain impact. The emergence of educational globalization means that the previous education models, methods and contents may undergo in-depth reforms, which is also an opportunity for the transformation of traditional cultural education into modern cultural education. In addition, the emergence of educational globalization has also strengthened the dependence among different countries. It helps to balance the allocation of the educational resources. The coexistence of 
education localization and educational similarity is an inevitable trend of education development in the world.

\section{ACKNOWLEDGMENT}

Thanks for all the scholars who give me the help. Meanwhile I'd like to show my gratitude to the support of my friends and family.

\section{REFERENCES}

[1] Little, J.W. Teacher development and educational policy. In Michael Fullan \& Andy Hargreaves (EDs), Teacher development and educational change. London \& Washington, D.C. : Falmet press, 1992, pp.186-187.

[2] 2. Seongwoo Choi: Medical Informatics. Gachon Medical School. Korea, 2002.

[3] Ryuko Kubota. The impact of globalization on language teaching in Japan, Globalization and language teaching, 23-38, 2002.

[4] Bala Kumaravadivelu. Cultural globalization and language education, Yale University Press, 2008.

[5] Claire Kramsch, Teaching foreign languages in an era of globalization: Introduction, The modern language journal 98 (1), 296-311, 2014.

[6] Peter Scott, The Globalization of Higher Education, Higher Education Re-formed, 101-118, 2005.

[7] Mark Warschauer, The changing global economy and the future of English teaching, Tesol Quarterly 34 (3), 511-535, 2000. 